\title{
INTERPROFESSIONAL EDUCATION (IPE) IMPROVES STUDENTS' COMMUNICATION SKILLS: A LITERATURE REVIEW
}

\author{
Sri Sundari ${ }^{*}$, Hadi Rai ${ }^{2}$ \\ ${ }^{1}$ School of Medicine, Faculty of Medicine and Health Sciences, Universitas Muhammadiyah Yogyakarta, Yogyakarta - INDONESIA \\ ${ }^{2}$ STIKes YARSI Pontianak, Pontianak - INDONESIA
}

Submitted: 11 Jan 2021; Final Revision from Authors: 12 Apr 2021; Accepted: 23 Apr 2021

\begin{abstract}
Background: Interprofessional education is a useful method for enhancing professional abilities in collaborative processes so as to create holistic health services. To improve collaboration skills, one of the competencies is the ability to communicate between professions. Therefore, it is necessary to know the existence of scientific evidence about the implementation of interprofessional education in improving student communication skills.
\end{abstract}

Method: There was some original research which was published in the ProQuest and Google Scholar databases from 2013 to 2017.

Results: There were 14 articles gotten from both inclusion and exclusion criteria. Articles collected using a quasiexperimental research design, and mix methods. Each article used a different implementation method to measure an increase in communication skills between students. Thirteen studies reported that students' communication skills increased, but there was one study that did not have a significance value for effective communication.

Conclusion: Based on the research review, there are many intervention methods that can be used to improve student communication in the application of IPE. Thus, institutions can improve, manage learning strategies and implement IPE.

Keywords: Interprofessional education, communication skills, multiprofession

\section{ABSTRAK}

Latar belakang: Interprofessional education merupakan metode yang berguna untuk meningkatkan kemampuan profesional dalam proses kolaboratif sehingga menciptakan pelayanan kesehatan yang holistik. Untuk meningkatkan kemampuan kolaborasi, salah satu kompetensi adalah kemampuan berkomunikasi antar profesi. Oleh karena itu perlu diketahui adanya bukti ilmiah tentang penerapan Interprofessional education dalam meningkatkan kemampuan komunikasi mahasiswa.

Metode: Paper berbahasa Inggris yang dipublikasikan di database ProQuest dan Google Scholar mulai tahun 2013 sampai 2017.

Hasil: Hasil penyaringan artikel yang didasarkan pada kriteria inklusi dan eksklusi didapatkan 14 artikel yang sesuai dari 211 artikel yang didapat. Artikel yang dikumpulkan menggunakan desain penelitian quasi experiment, dan mix methods. Setiap artikel menggunakan metode implementasi yang berbeda untuk melihat adanya peningkatan kemampuan komunikasi antar mahasiswa. Tiga belas penelitian tersebut melaporkan bahwa kemampuan komunikasi mahasisawa meningkat, namun ada satu penelitian yang tidak memiliki nilai signifikansi pada komunikasi yang efektif.

*corresponding author, contact: sundari_purbo@yahoo.com.sg 
Kesimpulan: Berdasarkan tinjauan penelitian ternyata banyak metode intervensi yang dapat di lakukan untuk meningkatkan komunikasi mahasiswa dalam penerapan IPE. Dengan demikian, institusi dapat meningkatkan, mengatur strategi pembelajaran serta menerapkan IPE yang optimal untuk meningkatkan dan mengembangkan kerja sama lintas profesi.

Kata kunci: Interprofessional education, ketrampilan komunikasi, multiprofesi

\section{PRACTICE POINTS}

- IPE merupakah salah satu cara pembelajaran di tahap sarjana agar antar profesi kesehatan mampu bekerja sama ketika mereka bekerja.

- Kemampuan kerjasama interprofesi diharapkan akan dapat meningkatkan patient safety dan mengurangi pembiayaan kesehatan.

- Komunikasi merupakan kunci utama dalam melaksanakan kerjasama interprofesi dapat berjalan dengan baik.

\section{PENDAHULUAN}

World Health Organization (WHO) ${ }^{1}$ menyebutkan bahwa pendidikan interprofessional education (IPE) terjadi ketika dua atau lebih profesi belajar satu sama lain untuk melakukan kolaborasi yang efektif sehingga dapat meningkatkan kesehatan secara optimal. Interprofessional education merupakan metode yang berguna untuk meningkatkan kemampuan profesional dalam proses kolaboratif. Salah satu tujuan IPE adalah untuk menciptakan layanan kesehatan holistik bersama dengan kelompok profesional untuk mengatasi masalah lintas profesi. Tujuan lain yang ingin dicapai dengan penerapan IPE adalah untuk meningkatkan kepercayaan dan komunikasi di antara lintas profesional, yang akhirnya mengarah pada perubahan sikap dan persepsi yang mungkin dimiliki anggota terhadap disiplin ilmu lainnya. ${ }^{2}$

Kemampuan untuk bekerja bersama dengan profesi lain untuk memberikan perawatan kolaboratif, yang berpusat pada pasien, dianggap sebagai elemen penting dari praktik profesional yang membutuhkan serangkaian kompetensi tertentu. Dua kompetensi inti yang harus dimiliki dalam praktek kolaborasi adalah memahami dan menghargai peran dan tanggung jawab profesional serta berkomunikasi secara efektif. ${ }^{3}$ Komunikasi interpersonal yang baik akan meningkatkan kualitas pelayanan, mengurangi medical errors dan menciptakan kolaborasi interprofesi yang baik. Komunikasi bisa bersifat interaktif, transaktif, verbal, nonverbal dan bervariasi dalam berbagai bentuk dan gaya. ${ }^{4}$ WHO menjelaskan bahwa $70-80 \%$ kesalahan yang terjadi di pelayanan kesehatan, diakibatkan oleh buruknya komunikasi dan kurangnya pemahaman anggota tim. ${ }^{5}$

World Health Organization (WHO) menyebutkan bahwa banyak sistem kesehatan di seluruh dunia terpecah-pecah dan berjuang untuk mengelola kebutuhan kesehatan yang tidak terpenuhi. Tenaga kerja masa sekarang dan masa depan bertugas untuk menyediakan layanan kesehatan dalam menghadapi masalah kesehatan yang semakin kompleks. Bukti menunjukkan bahwa saat petugas kesehatan melaksanakan sistem ini, kesempatan bagi mereka untuk mendapatkan pengalaman interprofessional, dapat membantu mereka mempelajari keterampilan yang dibutuhkan untuk menjadi bagian dari tenaga kesehatan yang siap kerja dan melakukan kolaborasi. ${ }^{1}$

Mahasiswa belajar berkolaborasi dan berkomunikasi secara efektif. Dengan melakukan kolaborasi 
tersebut, selain mereka mengembangkan kualitas kepemimpinan mereka juga bisa berlatih untuk saling menghormati pengetahuan dan keahlian satu sama lain ${ }^{6}$. Metode ini dianggap sangat penting untuk kesuksesan dalam proses koordinasi tim perawatan kesehatan di mana fungsionalitas tim dan keselamatan pasien menjadi prioritas. Perawat bisa memanfaatkan keahlian mereka bersama dokter dan profesional kesehatan lainnya dengan cara yang efektif sebagai anggota vital dari tim, serta sebagai pemimpin dalam tim, mendukung anggota tim lainnya. Dengan mengasah keterampilan praktik kerja sama dalam pemprograman IPE, profesional keperawatan di semua tingkatan akan lebih mungkin untuk memanfaatkan keterampilan ini dalam praktik klinis mereka sendiri. ${ }^{6}$

Komunikasi yang efektif memiliki beberapa hambatan, yaitu hambatan proses, hambatan fisik, hambatan semantik, dan hambatan psikososial. Untuk meningkatkan efektivitas komunikasi, harus mengembangkan kesadaran akan pentingnya tanggung jawab masing-masing serta mengembangkan kemampuan mendengarkan. ${ }^{6}$ Kurangnya kemampuan komunikasi dapat terjadi jika tidak adanya pelatihan atau pendidikan penerapan kolaborasi antar tenaga kesehatan. Kemampuan kolaborasi antar tenaga kesehatan dapat ditingkatkan melalui perubahan proses pendidikan professional. ${ }^{7}$ Persiapan pembelajaran yang lebih lanjut diperlukan untuk mengembangkan kemampuan komunikasi antara tenaga kesehatan sehingga meningkatkan kerjasama yang kompeten, berkualitas, serta berorientasi pada pelayanan, salah satu metode yang dapat digunakan adalah melalui interprofessional education.

Hasil penelitian yang dilakukan oleh beberapa peneliti mengatakan penerapaan interprofessional education dapat meningkatkan keterampilan komunikasi serta pemahaman tentang peran mereka sebagai penyedia layanan kesehatan dalam meningkatkan persepsi mahasiswa tentang peran mereka sendiri di dalam tim. Adanya perubahan positif mengenai peran dan tanggung jawab dalam tim dalam berkomunikasi, serta komunikasi interprofesional sangat diperlukan dalam kerja sama. ${ }^{8}$ Namun ada penelitian yang bertentangan dengan hasil penelitian tersebut yaitu penerapan IPE tidak mendukung kemampuan komunikasi yang efektif.

Berdasarkan uraian fenomena dan kasus di atas, penulis ingin mengetahui lebih mendalam bagaimana kemampuan komunikasi mahasiswa dalam pelaksanaan Interprofessional education (IPE).

\section{METODE}

Tulisan ini bertujuan untuk melihat perkembangan penerapan Interprofessional education terhadap kemampuan komunikasi mahasiswa. Pencarian literatur melalui database yang relevan (ProQuest dan Google Scholar), pertimbangan daftar referensi dari artikel yang dipilih, dan meninjau rekomendasi dari para ahli. Database ProQuest dicari dengan menggunakan kode student and implementation of IPE and communication skills, sedangkan Google Scholar dengan istilah "student" + "implementation of IPE" + "communication skills". Kriteria inklusi pada literatur ini yaitu artikel bahasa Inggris yang dipublikasikan dari tahun 2013 sampai 2017, artikel dalam bentuk full teks. Kriteria ekslusi yaitu artikel publikasi tidak dalam bentuk publikasi tidak asli seperti surat ke editor, abstrak, buku dan artikel berbayar. Dari sejumlah artikel yang diperoleh pertama kali ditinjau berdasarkan kesesuaian judul, setelah itu direview menggunakan abstrak dan full teks sehingga diperoleh 14 artikel yang sesuai untuk direview.

\section{HASIL DAN PEMBAHASAN}

Fokus utama kajian literatur review ini adalah pada kemampuan komunikasi mahasiswa terhadap penerapan Interprofessional education (IPE). Untuk mengoptimalkan interpretasi ini, pertama-tama kita akan mengklarifikasi temuan hasil penelitian. Strategi pencarian awal mengidentifikasi 211 publikasi dari dua database utama. 211 publikasi untuk review judul, 150 artikel terbitan dikeluarkan karena tidak relevan berdasarkan peninjauan judul. 61 abstrak ditinjau ulang dan 47 dianggap tidak relevan. Tinjauan lengkap dilakukan sebanyak 14 artikel yang memenuhi kriteria inklusi dan analisis hasil (Gambar 1). 


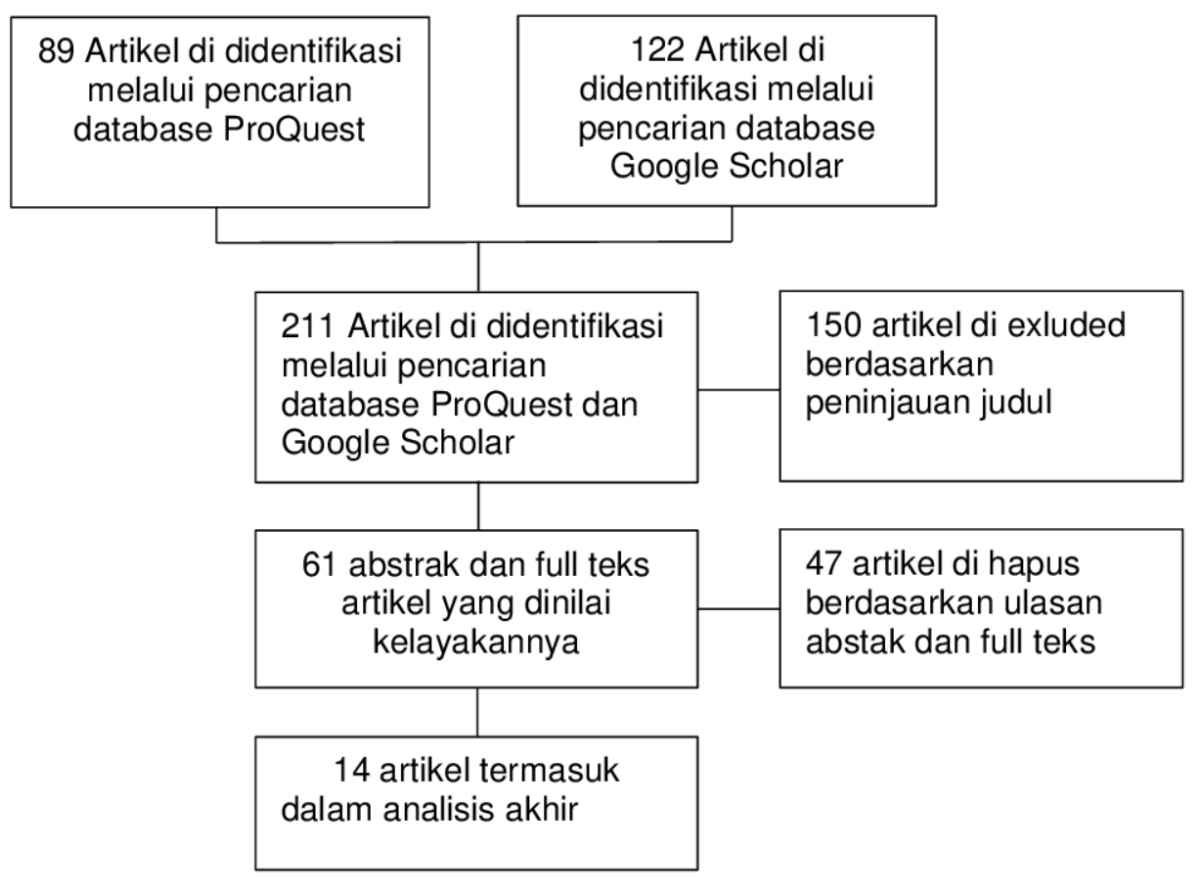

Gambar 1. Bagan alir pencarian literatur

Di antara 14 studi yang ditinjau, delapan penelitian memiliki rancangan mixed methods, $, 10,13-16,19,20$ dua penelitian adalah quasi-eksperimental, ${ }^{8,17}$ dua penelitian adalah survey, ${ }^{12,13}$ satu penelitian adalah pre dan post-intervention survey, ${ }^{18}$ dan satu penelitian adalah post retrospektif. ${ }^{17}$ Dari 14 penelitian tersebut, tiga penelitian menggunakan course, ${ }^{17,19}$ tiga penelitian menggunakan metode clinical laboratory/ simulation,,$^{16,17,20}$ satu penelitian menggunakan experience/modul, ${ }^{9}$ satu penelitian menggunakan modul and case study, ${ }^{8}$ satu penetilitan menggunakan laboratory session dan viewed short videos, ${ }^{18}$ dua penelitian menggunakan focus group discussions, ${ }^{10,14}$ dua penelitian menggunakan question for the survey instrument, ${ }^{10,12}$ dan satu penelitian menggunakan student worked in preselected groups. ${ }^{15}$ Di antara 14 penelitian tersebut, tiga belas studi melaporkan bahwa kemampuan komunikasi mahasiswa meningkat, ${ }^{4,8-10,12,14-20}$ namun, ada satu penelitian yang tidak memiliki nilai signifikasi pada komunikasi yang efektif. ${ }^{13}$ Karakteristik dari 14 studi yang ditinjau dapat dilihat pada Tabel 1.

Tabel 1. Karakteristik studi yang dikaji

\begin{tabular}{|c|c|c|c|c|c|}
\hline $\begin{array}{l}\text { Penulis, } \\
\text { tahun }\end{array}$ & $\begin{array}{l}\text { Data } \\
\text { base }\end{array}$ & Judul & $\begin{array}{l}\text { Metode/ } \\
\text { desain } \\
\text { penelitian }\end{array}$ & $\begin{array}{c}\text { Metode } \\
\text { penerapan }\end{array}$ & Hasil \\
\hline $\begin{array}{l}\text { Baker, } \\
\text { Maureen J, } \\
\text { and Durham } \\
\text { Carol } \\
\text { Fowler, } 2013\end{array}$ & ProQuest & $\begin{array}{l}\text { Interprofessional } \\
\text { Education: } \\
\text { A Survey of } \\
\text { Students' } \\
\text { Collaborative } \\
\text { Competency } \\
\text { Outcomes }\end{array}$ & Desain survey & $\begin{array}{l}\text { interprofessional } \\
\text { education (IPE) } \\
\text { course }\end{array}$ & $\begin{array}{l}\text { Kerja sama tim interprofessional } \\
\text { dan kursus komunikasi } \\
\text { berpengaruh terhadap } \\
\text { kompetensi kolaboratif } \\
\text { mahasiswa serta peningkatan } \\
\text { komunikasi, kolaborasi, } \\
\text { pemahaman tentang peran dan } \\
\text { tanggung jawab yang lebih baik. }\end{array}$ \\
\hline
\end{tabular}




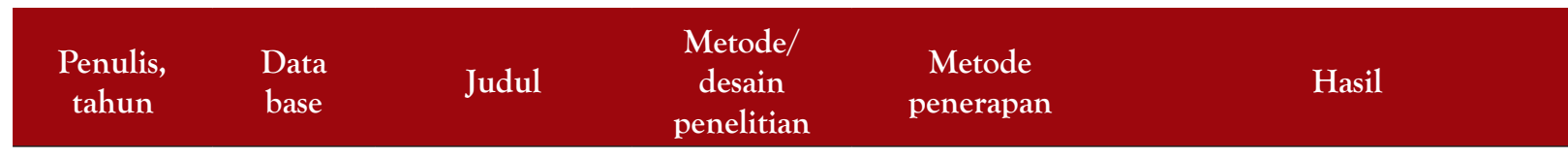

\begin{tabular}{|c|c|c|c|c|}
\hline $\begin{array}{l}\text { Bolesta, } \\
\text { Scott and } \\
\text { Chmil, Joyce } \\
\text { V, } 2014\end{array}$ & ProQuest & $\begin{array}{l}\text { Interprofessional } \\
\text { education among } \\
\text { student health } \\
\text { professionals } \\
\text { using human } \\
\text { patient } \\
\text { simulation }\end{array}$ & $\begin{array}{l}\text { Quasi } \\
\text { eksperimental }\end{array}$ & $\begin{array}{l}\text { Clinical } \\
\text { laboratory using } \\
\text { human patient } \\
\text { simulation }\end{array}$ \\
\hline
\end{tabular}

Ada peningkatan dalam sikap mahasiswa terhadap IPE setelah partisipasi dalam lokakarya. Mahasiswa mengatakan lebih siap untuk pengalaman IPE di masa depan dan mengindikasikan bahwa laboratorium dapat membantu mengembangkan keterampilan komunikasi interprofessional mereka.

\begin{tabular}{|c|c|c|}
\hline $\begin{array}{l}\text { Butler, } \\
\text { Michelle, } \\
2016\end{array}$ & $\begin{array}{l}\text { Google } \\
\text { Scholar }\end{array}$ & $\begin{array}{l}\text { Students' } \\
\text { experiences of } \\
\text { interprofessional } \\
\text { education in the } \\
\text { Faculty of Health } \\
\text { Sciences at the } \\
\text { University of the } \\
\text { Free State }\end{array}$ \\
\hline
\end{tabular}

$\begin{array}{ll}\text { Mix Methods } & \begin{array}{l}\text { Experience } \\ \text { provided during } \\ \text { the IPE module }\end{array}\end{array}$

Mahasiswa menunjukkan pengambilan keputusan bersama the IPE module dan kekuatan bersama melalui komunikasi dan kolaborasi dengan tim layanan kesehatan dan pasien serta keluarga. Namun, dalam proses menghadiri dan berpartisipasi dalam IPE, para peserta mengidentifikasi lebih banyak kebutuhan berkaitan dengan dapat mencapai tujuan ini dan mampu mengambil keterampilan belajar ke tempat kerja mereka.

\begin{tabular}{|c|c|c|c|c|c|}
\hline $\begin{array}{l}\text { Christenson, } \\
\text { Shaun, } 2014\end{array}$ & $\begin{array}{l}\text { Google } \\
\text { Scholar }\end{array}$ & $\begin{array}{l}\text { Interprofessional } \\
\text { Education on } \\
\text { Oral Care for } \\
\text { Cancer Patients } \\
\text { in Dental } \\
\text { Hygiene and } \\
\text { Nursing } \\
\end{array}$ & $\begin{array}{l}\text { Quasi- } \\
\text { experimental } \\
\text { study }\end{array}$ & $\begin{array}{l}\text { A module of IPE } \\
\text { and a case study }\end{array}$ & $\begin{array}{l}\text { Ada peningkatan sikap } \\
\text { mahasiswa tentang kemampuan } \\
\text { berkomunikasi dan pemahaman } \\
\text { tentang peran mereka sebagai } \\
\text { penyedia layanan kesehatan. }\end{array}$ \\
\hline $\begin{array}{l}\text { Kirwin, et al, } \\
2017\end{array}$ & ProQuest & $\begin{array}{l}\text { Interprofessional } \\
\text { Curbside } \\
\text { Consults to } \\
\text { Develop Team } \\
\text { Communication } \\
\text { and Improve } \\
\text { Student } \\
\text { Achievement } \\
\text { of Learning } \\
\text { Outcomes }\end{array}$ & $\begin{array}{l}\text { Pre- and Post- } \\
\text { intervention } \\
\text { Survey }\end{array}$ & $\begin{array}{l}\text { Laboratory } \\
\text { session, } \\
\text { listened to a } \\
\text { classroom lecture } \\
\text { about team } \\
\text { communication } \\
\text { and viewed short } \\
\text { videos describing } \\
\text { the roles. }\end{array}$ & $\begin{array}{l}\text { Hasil survei menunjukkan sikap } \\
\text { positif yang diberikan tim pada } \\
\text { tingkat awal, dan peningkatan } \\
\text { yang signifikan pada } 17 \text { dari } \\
30 \text { item (P-value } 0,05 \text { ) setelah } \\
\text { menyelesaikan tugas konsultasi } \\
\text { antar department. Selain itu, } \\
\text { adanya perbaikan yang terlihat. } \\
\text { pada dua hal yaitu berkaitan } \\
\text { dengan komunikasi: "Saya lebih } \\
\text { suka bekerja dengan anggota tim } \\
\text { yang mengajukan pertanyaan } \\
\text { tentang informasi yang saya } \\
\text { berikan" dan "Penting untuk } \\
\text { memiliki metode standar untuk } \\
\text { berbagi informasi" }\end{array}$ \\
\hline
\end{tabular}




\begin{tabular}{|c|c|c|c|c|c|}
\hline $\begin{array}{l}\text { Penulis, } \\
\text { tahun }\end{array}$ & $\begin{array}{l}\text { Data } \\
\text { base }\end{array}$ & Judul & $\begin{array}{l}\text { Metode/ } \\
\text { desain } \\
\text { penelitian }\end{array}$ & $\begin{array}{c}\text { Metode } \\
\text { penerapan }\end{array}$ & Hasil \\
\hline $\begin{array}{l}\text { Kostoff, } \\
\text { Matthew, et } \\
\text { al } 2016\end{array}$ & ProQuest & $\begin{array}{l}\text { An } \\
\text { interprofessional } \\
\text { simulation } \\
\text { using the SBAR } \\
\text { communication } \\
\text { tool }\end{array}$ & Mix methods & $\begin{array}{l}\text { Participated } \\
\text { in an } \\
\text { interprofessional } \\
\text { simulation } \\
\text { within a required } \\
\text { applications- } \\
\text { based capstone } \\
\text { course. Pharmacy } \\
\text { students } \\
\text { collaborated with } \\
\text { nursing students } \\
\text { on multiple } \\
\text { patient cases in } \\
\text { various settings } \\
\text { using the SBAR } \\
\text { communication } \\
\text { tool over the } \\
\text { telephone }\end{array}$ & $\begin{array}{l}\text { Alat komunikasi SBAR secara } \\
\text { positif mempengaruhi persepsi } \\
\text { diri mahasiswa farmasi terhadap } \\
\text { kompetensi interprofessional, } \\
\text { reaksi terhadap kolaborasi antar } \\
\text { professional, dan perhatian } \\
\text { karena teknik pengajaran SBAR. }\end{array}$ \\
\hline
\end{tabular}

\begin{tabular}{|c|c|c|c|c|c|}
\hline $\begin{array}{l}\text { Lestari, } \\
\text { Endang, et } \\
\text { al, } 2016\end{array}$ & $\begin{array}{l}\text { Google } \\
\text { Scholar }\end{array}$ & $\begin{array}{l}\text { Understanding } \\
\text { students' } \\
\text { readiness for } \\
\text { interprofessional } \\
\text { learning in an } \\
\text { Asian context: a } \\
\text { mixed-methods } \\
\text { study }\end{array}$ & Mix Methods & $\begin{array}{l}\text { Conducted } \\
4 \text { mono- } \\
\text { professional } \\
\text { focus group } \\
\text { discussions } \\
\text { (FGDs) }\end{array}$ & $\begin{array}{l}\text { Keterpaparan dini terhadap } \\
\text { praktik klinis memicu persepsi } \\
\text { IPE positif dan negatif untuk } \\
\text { meningkatkan keterampilan } \\
\text { komunikasi dan kepemimpinan }\end{array}$ \\
\hline $\begin{array}{l}\text { Maldonado, } \\
\text { Angela Q, et } \\
\text { al, } 2013\end{array}$ & ProQuest & $\begin{array}{l}\text { Impact of } \\
\text { participation } \\
\text { on a solid organ } \\
\text { transplant team } \\
\text { on student } \\
\text { pharmacists' } \\
\text { perceptions of } \\
\text { interprofessional } \\
\text { roles }\end{array}$ & Design survey & $\begin{array}{l}\text { Questions } \\
\text { for the survey } \\
\text { instrument }\end{array}$ & $\begin{array}{l}\text { Perubahan positif terlihat } \\
\text { di bidang kompetensi inti } \\
\text { interprofessional education } \\
\text { mengenai peran, tanggung jawab, } \\
\text { komunikasi interprofessional dan } \\
\text { kerja sama tim. }\end{array}$ \\
\hline $\begin{array}{l}\text { Rothmund, } \\
\text { Windy L, } \\
2016\end{array}$ & $\begin{array}{l}\text { Google } \\
\text { Scholar }\end{array}$ & $\begin{array}{l}\text { Oral } \\
\text { manifestations of } \\
\text { menopause: an } \\
\text { interprofessional } \\
\text { intervention for } \\
\text { dental hygiene } \\
\text { and physician } \\
\text { assistant students }\end{array}$ & Mix Methods & $\begin{array}{l}\text { Readiness for } \\
\text { Interprofessional } \\
\text { Learning Survey } \\
\text { (RIPLS) and } \\
\text { Students worked } \\
\text { in preselected } \\
\text { groups }\end{array}$ & $\begin{array}{l}\text { Peningkatan sikap terhadap kerja } \\
\text { sama tim interprofessional dan } \\
\text { kolaborasi, identitas profesional, } \\
\text { peran, tanggung jawab dan } \\
\text { komunikasi interprofessional. } \\
\text { Menunjukkan kepercayaan diri } \\
\text { dalam menerapkan keterampilan } \\
\text { baru. }\end{array}$ \\
\hline
\end{tabular}




\begin{tabular}{|c|c|c|c|c|c|}
\hline $\begin{array}{l}\text { Penulis, } \\
\text { tahun }\end{array}$ & $\begin{array}{l}\text { Data } \\
\text { base }\end{array}$ & Judul & $\begin{array}{l}\text { Metode/ } \\
\text { desain } \\
\text { penelitian }\end{array}$ & $\begin{array}{c}\text { Metode } \\
\text { penerapan }\end{array}$ & Hasil \\
\hline $\begin{array}{l}\text { Schwanz, } \\
\text { Brandy, } 2017\end{array}$ & $\begin{array}{l}\text { Google } \\
\text { Scholar }\end{array}$ & $\begin{array}{l}\text { Interprofessional } \\
\text { education in the } \\
\text { clinical setting: } \\
\text { An exploration } \\
\text { of the attitudes, } \\
\text { knowledge, } \\
\text { and skills of } \\
\text { physical therapist } \\
\text { students } \\
\text { and physical } \\
\text { therapist clinical } \\
\text { instructors }\end{array}$ & Mix Methods & $\begin{array}{l}\text { Using the } \\
\text { Interprofessional } \\
\text { Education } \\
\text { Collaborative } \\
\text { (IPEC) } \\
\text { Competency } \\
\text { Survey } \\
\text { Instrument and } \\
\text { interviews were } \\
\text { conducted with } \\
\text { both students } \\
\text { and clinical } \\
\text { instructors. }\end{array}$ & $\begin{array}{l}\text { Komunikasi, peran dan tanggung } \\
\text { jawab lebih jelas kepada pasien, } \\
\text { keluarga dan lainnya. Komunikasi } \\
\text { Interpersonal kepercayaan } \\
\text { diri mahasiswa menjadi paling } \\
\text { kompeten. }\end{array}$ \\
\hline $\begin{array}{l}\text { Scott, Ann } \\
\text { D, } 2017\end{array}$ & $\begin{array}{l}\text { Google } \\
\text { Scholar }\end{array}$ & $\begin{array}{l}\text { Simulation-Based } \\
\text { Interprofessional } \\
\text { Education in a } \\
\text { Rural Setting }\end{array}$ & Mix Methods & $\begin{array}{l}\text { Examined the } \\
\text { feasibility of } \\
\text { implementing } \\
\text { a simulation- } \\
\text { based IPE } \\
\text { experience using } \\
\text { telehealth tools; } \\
\text { and Evaluated } \\
\text { student } \\
\text { perceptions of } \\
\text { interprofessional } \\
\text { teamwork, } \\
\text { roles and } \\
\text { responsibilities, } \\
\text { and patient } \\
\text { outcomes for } \\
\text { collaborative } \\
\text { practice, both } \\
\text { pre- and post- } \\
\text { scenario. }\end{array}$ & $\begin{array}{l}\text { Data kuantitatif dianalisis } \\
\text { menunjukkan hasil 94\% setuju } \\
\text { bahwa pengalaman IPE mirip } \\
\text { dengan situasi kehidupan } \\
\text { nyata. Data kualitatif dianalisis } \\
\text { menghasilkan empat tema yaitu: } \\
\text { 1) pemahaman teknologi yang } \\
\text { lebih baik; 2) meningkatkan } \\
\text { komunikasi antar anggota tim; } \\
\text { 3) manfaat pengalaman hidup } \\
\text { sejati; dan 4) tingkat pengetahuan } \\
\text { meningkat dan kepercayaan. } \\
\text { Saran peserta untuk perbaikan } \\
\text { meliputi: 1) memperbaiki } \\
\text { simulasi / orientasi peralatan } \\
\text { telehealth; 2) pertimbangkan } \\
\text { simulasi tipe round grand; dan } \\
\text { 3) mengatasi tantangan teknis } \\
\text { dengan robot }\end{array}$ \\
\hline $\begin{array}{l}\text { Sevin, Alexa } \\
\text { M, et al, } \\
2016\end{array}$ & ProQuest & $\begin{array}{l}\text { Assessing } \\
\text { interprofessional } \\
\text { education } \\
\text { collaborative } \\
\text { competencies in } \\
\text { service-learning } \\
\text { course }\end{array}$ & $\begin{array}{l}\text { Post-then-Pre } \\
\text { Retrospektif }\end{array}$ & $\begin{array}{l}\text { The semester- } \\
\text { long elective } \\
\text { course }\end{array}$ & $\begin{array}{l}\text { Kemampuan komunikasi } \\
\text { dengan kolega membuat konsep } \\
\text { sama dengan kehidupan nyata } \\
\text { dan pengalaman kerja sama } \\
\text { interprofessional berharga } \\
\text { untuk dipelajari terkait peran } \\
\text { profesi lainnya dan memberi } \\
\text { mereka pandangan yang lebih } \\
\text { lengkap mengenai kesehatan di } \\
\text { masyarakat. }\end{array}$ \\
\hline
\end{tabular}




\begin{tabular}{|c|c|c|c|c|c|}
\hline $\begin{array}{c}\text { Penulis, } \\
\text { tahun }\end{array}$ & $\begin{array}{l}\text { Data } \\
\text { base }\end{array}$ & Judul & $\begin{array}{c}\text { Metode/ } \\
\text { desain } \\
\text { penelitian }\end{array}$ & $\begin{array}{c}\text { Metode } \\
\text { penerapan }\end{array}$ & Hasil \\
\hline $\begin{array}{l}\text { Shrader, } \\
\text { Sarah, et al, } \\
2016\end{array}$ & ProQuest & $\begin{array}{l}\text { Using } \\
\text { communication } \\
\text { technology } \\
\text { to enhance } \\
\text { interprofessional } \\
\text { education } \\
\text { simulations }\end{array}$ & Mix methods & $\begin{array}{l}\text { Students were } \\
\text { randomly } \\
\text { assigned to } \\
\text { one of three } \\
\text { interprofessional } \\
\text { education (IPE) } \\
\text { simulations with } \\
\text { other health } \\
\text { professions } \\
\text { students using } \\
\text { communication } \\
\text { methods such } \\
\text { as telephone, } \\
\text { e-mail, and video } \\
\text { conferencing. }\end{array}$ & $\begin{array}{l}\text { Hasil penelitian ditemukan } \\
\text { dari } 80 \% \text { mahasiswa } \\
\text { meyakinkan adanya komunikasi } \\
\text { interprofessional. Mahasiswa } \\
\text { merasa bahwa simulasi } \\
\text { membantu menunjukkan betapa } \\
\text { pentingnya kerja sama tim untuk } \\
\text { mencapai tujuan bersama. }\end{array}$ \\
\hline $\begin{array}{l}\text { Sincak, } \\
\text { Carrie, et al, } \\
2017\end{array}$ & ProQuest & $\begin{array}{l}\text { Transformation } \\
\text { of an Online } \\
\text { Multidisciplinary } \\
\text { Course } \\
\text { into a Live } \\
\text { Interprofessional } \\
\text { Experience }\end{array}$ & Mix methods & $\begin{array}{l}\text { Students were } \\
\text { placed in } \\
\text { interprofessional } \\
\text { groups and } \\
\text { met weekly to } \\
\text { participate in } \\
\text { didactic lectures, } \\
\text { discussion } \\
\text { sessions, and } \\
\text { a standardized } \\
\text { patient } \\
\text { encounter. }\end{array}$ & $\begin{array}{l}\text { Hasil penelitian tidak } \\
\text { menunjukkan perubahan } \\
\text { yang signifikan dari waktu ke } \\
\text { waktu. Salah satu interpretasi } \\
\text { dari temuan ini adalah bahwa } \\
\text { variabel pentingnya memberikan } \\
\text { perawatan pasien berkualitas } \\
\text { tinggi atau komunikasi tidak } \\
\text { menghasilkan menghasilkan } \\
\text { perubahan apa pun. Sebagai } \\
\text { alternatif, cara ini menunjukkan } \\
\text { bahwa skor sudah cukup tinggi } \\
\text { pada Waktu } 1 \text {, dan bahwa tidak } \\
\text { ada perubahan setelah diamati. }\end{array}$ \\
\hline
\end{tabular}

Secara keseluruhan, literature review ini terdiri dari 14 artikel. Tiga belas dari penelitian tersebut melaporkan bahwa penerapan IPE dapat meningkatkan komunikasi pada mahasiswa. ${ }^{4-21}$ Tedapat berbagai macam kendala dalam pelaksanaan kolaborasi interprofesi antara lain kurang percaya diri, tidak tahu peran dan tanggung jawab masingmasing profesi, kurang mampu bekerja secara tim, tidak percaya diri dalam menerapkan ketrampilan baru dan berkomunikasi interprofesi. Penerapan IPE dapat meningkatkan komunikasi, kolaborasi, peran dan tanggung jawab., 40,12,15 Selain itu ada kemampuan lain yang meningkat setelah penerapan IPE di antaranya peningkatan sikap mahasiswa, ${ }^{17,18}$ peningkatan persepsi diri mahasiswa, ${ }^{20}$ serta meningkatkan pengalaman dan pengambilan keputusan..$^{9,16,21}$ Namun, ada satu penelitian yang menyatakan bahwa IPE tidak menunjukkan hasil perubahan yang signifikan terhadap komunikasi interprofessional. ${ }^{13}$

Secara keseluruhan hasil artikel penelitian menunjukkan keefektifan terkait penerapan IPE terhadap peningkatan komunikasi mahasiswa. Terdapat faktor yang menunjang pada literature review ini yaitu penelitian bersifat heterogen yang berkaitan dengan tujuan dan model intervensi penerapan IPE di pendidikan, serta adanya variasi lintas profesi seperti terapi okupasi, keperawatan, fisioterapi, optometri, mahasiswa biokinetik, ${ }^{17}$ kedokteran, keperawatan, kebidanan dan kedokteran gigi. ${ }^{9}$

Literature review ini juga menunjukkan bahwa pembelajaran kolaborasi interprofesi dapat diberikan 
melalui berbagai metode intervensi misalnya menggunakan sesi laboratorium, mendengarkan kuliah kelas tentang komunikasi tim dan melihat video pendek, ${ }^{8}$ sedangkan penelitian mengunakan metode simulasi interprofessional dalam kursus ujian berbasis aplikasi, mahasiswa farmasi berkolaborasi dengan siswa keperawatan pada beberapa kasus pasien di berbagai tempat menggunakan alat komunikasi SBAR melalui telepon. ${ }^{18}$ Model pembelajaran kolaborasi interprofesi juga dapat diberikan di berbagai tahap pembelajaran mulai dari tahap awal sampai tingkat akhir. Lebih jauh lagi, sebagian besar studi yang disertakan melibatkan ukuran sampel yang kecil, data yang dilaporkan seperti survei tanggapan ICCAS, mengandung sumber bias yang potensial. ${ }^{4}$

Sevin et al. ${ }^{21}$ menyadari bahwa mahasiswa profesi kesehatan perlu dipersiapkan berlatih secara kolaboratif untuk menyediakan layanan berkualitas dan berpusat pada pasien. Mengingat IPE merupakan dua atau lebih profesi yang saling belajar satu sama lain untuk menhasilkan kolaborasi yang efektif serta meningkatkan kesehatan yang optimal. ${ }^{22}$ Sebagai tambahan, mengingat kurangnya bukti tentang dampaknya IPE mengenai sumber daya (misalnya biaya dan manfaat), penelitian lebih lanjut dibutuhkan di area ini, ${ }^{20}$ sehingga perlu di lihat perkembangan dan peningkatan penerapan IPE di berbagai institusi.

IPE merupakan salah satu dari beberapa komponen yang relevan dengan kurikulum pendidikan kesehatan menyeluruh, karena dapat membantu meningkatkan komunikasi dan kerja tim di antara lintas profesi kesehatan, mengoptimalkan pembuatan keputusan klinis kolaboratif, dan memperbaiki penyampaian dan kualitas layanan pasien. Harapannya adalah bahwa lulusan praktikum yang siap bekerjasama akan menerapkan strategi kerja sama dan kemampuan komunikasi timbal balik yang mereka pelajari pada titik asuhan. ${ }^{4}$

Kolaborasi interprofessional diidentifikasi sebagai hal yang penting untuk penyediaan layanan kesehatan yang efektif dan efisien, mengingat kompleksitas kebutuhan perawatan kesehatan pasien dan jangkauan penyedia layanan kesehatan dan organisasi. Sehubungan dengan penerapan IPE memiliki tahapan yang berbeda dalam pengembangan professional sehingga memungkinkan untuk diterapkan. ${ }^{20}$

Pada dasarnya komunikasi adalah berbagi informasi, baik secara tertulis maupun secara lisan. Manusia menyampaikan informasi melalui berbagai metode. Namun, semua bentuk komunikasi memerlukan elemen dasar yang sama: pembicara atau pengirim informasi, pesan, dan audiens atau penerima. Pengirim dan penerima juga harus berbagi bahasa atau sarana untuk saling memahami agar komunikasi menjadi sukses. Dengan demikian, sebuah studi tentang komunikasi sering meneliti perkembangan dan struktur bahasa, termasuk bahasa matematika yang digunakan dalam pemrograman. ${ }^{15}$

Dengan IPE, mahasiswa belajar berkolaborasi dan berkomunikasi secara efektif, dan dengan melakukannya, mereka mengembangkan kualitas kepemimpinan dan saling menghormati pengetahuan dan keahlian satu sama lain ${ }^{1}$. Metode dan nilai ini sangat penting untuk kesuksesan dalam pengaturan tim perawatan kesehatan dimana fungsionalitas tim dan keselamatan pasien menjadi prioritas utama. Perawat bisa memanfaatkan keahlian mereka terlibat dengan dokter dan profesional kesehatan lainnya dengan cara yang efektif sebagai anggota vital dari tim dan sebagai pemimpin untuk mendukung anggota lainnya. Dengan mengasah keterampilan praktik kerja sama dalam pemrograman IPE, profesional keperawatan di semua tingkatan akan lebih mungkin untuk memanfaatkan keterampilan ini dalam praktik klinis mereka sendiri. ${ }^{6}$

\section{Keterbatasan penelitian}

Literatur review ini hanya mengambil artikel dari 2 database, akan lebih baik lagi jika database yang digunakan lebih banyak lagi.

\section{KESIMPULAN}

Penerapan IPE mampu meningkatkan kemampuan mahasiswa berkolaborasi dan berkomunikasi secara efektif, mengembangkan kualitas kepemimpinan dan saling menghormati pengetahuan dan keahlian satu sama lain. Kemampuan komunikasi yang baik, bermutu dan efektif, sikap saling menghormati antar 
profesi kesehatan dan saling menghormati peran profesi masing-masing akan dapat meningkatkan pelayanan kesehatan sehingga diharapkan dapat meningkatkan keselamatan pasien. Untuk meningkatkan kemampuan komunikasi ini dapat dilakukan dengan berbagai metode di antaranya melalui kursus, laboratorium klinis dengan pasien simulasi, pengalaman pembelajaran dengan modul IPE, studi kasus, praktek laboratorium, mendengarkan kuliah di kelas tentang komunikasi dalam tim dan melihat video yang menggambarkan masing-masing peran, simulasi, berbagai kasus yang menggunakan seting komunikasi menggunakan telepon dengan prinsip SBAR, focus group discussions (FGDs), bekerja di dalam kelompok atau grup, melakukan survei dengan wawancara menggunakan instrumen, kerjasama tim secara interprofesi serta melakukan komunikasi menggunakan telefon e-mail, dan konferensi menggunaan video.

\section{SARAN}

Untuk review literatur lebih lanjut akan lebih baik jika menggunakan kata kunci yang lebih banyak dan lebih bervariasi dalam pencarian artikel sehingga didapatkan artikel yang banyak pula.

\section{DEKLARASI PEPENTINGAN}

Para penulis mendeklarasikan bahwa tidak terdapat konflik kepentingan apapun terkait studi pada naskah ini.

\section{KONTRIBUSI PENULIS}

Sri Sundari - penulis utama berkontribusi dalam review artikel, penulisan manuskrip, evaluasi manuskrip dan revisi manuskrip.

Hadi Rai - penulis kedua berkontribusi dalam pencaraian artikel, review artikel, analisis hasil review, dan penulisan manuskrip.

\section{DAFTAR PUSTAKA}

1. WHO. Framework for Action on Interprofessional Education \& Collaborative Practice. Nursing \& Midwifery Human Resources for Health; 2010. (6)
2. Lumague $M$, Morgan A, Mak D, Hanna M, Kwong J, Cameron C, et al. Interprofessional education: The student perspective. J Interprof Care. 2006;20(3):246-53.

3. Esther Suter, Julia Arndt, Nancy Arthur, John Parboosingh, Elizabeth Taylor, \& Siegrid Deutschlander. 2009. Role Understanding and Effective Communication as Core Competencies For Collaborative Practice. Journal of Interprofessional Care, Informa Healthcare. 23(1): 41-51.

4. Setiadi, Adji dkk. Factors contributing to interprofessional collaboration in Indonesia health centres : A focus group study. Journal of Interprofessional Education \& Practice. 2017;8:69-74

5. World Health Organisation (WHO). Human Factors in Patient Safety Review of topics and Tools.World Health Organisation, Geneva; 2009.

6. Speakman E, et al. Guide to Effective Interprofessional Education Experiences in Nursing Education. National League for Nursing; 2015.

7. Lunenburg FC. Communication: The process, barriers, and improving effectiveness. Schooling. 2010;1(1):1-11.

8. Uswatun N, Orbayinah S. Tingkat kemampuan komunikasi antar profesi pada mahasiswa program pendidikan dokter dan farmasi yang terpapar Interprofessional Education (IPE) di Fakultas Kedokteran dan Ilmu Kesehatan Universitas Muhammadiyah Yogyakarta; 2016.

9. Christenson S. Interprofessional Education on Oral Care for Cancer Patients in Dental Hygiene and Nursing; 2014.

10. Maldonado AQ, Bray BS, Woodard LJ, BarbosaLeiker C, Hardinger KL, Wu V, et al. Impact of participation on a solid organ transplant team on student pharmacists' perceptions of interprofessional roles. Am J Pharm Educ. 2013;77(4):74.

11. Shrader S, Kostoff M, Shin T, Heble A, Kempin B, Miller A, et al. Using communication technology to enhance interprofessional 
education simulations. Am J Pharm Educ. 2016;80(1):13.

12. Sincak C, Gunn J, Conroy C, Komperda K, Van Kanegan K, Krumdick N, et al. Transformation of an Online Multidisciplinary Course into a Live Interprofessional Experience. Am J Pharm Educ. 2017;81(5):94

13. Butler M. Students' experiences of interprofessional education in the Faculty of Health Sciences at the University of the Free State. University of the Free State; 2016.

14. Kostoff M, Burkhardt C, Winter A, Shrader S. An interprofessional simulation using the SBAR communication tool. Am J Pharm Educ. 2016;80(9):157.

15. Lestari E, Stalmeijer RE, Widyandana D, Scherpbier A. Understanding students' readiness for interprofessional learning in an Asian context: a mixed-methods study. BMC Med Educ [Internet]. 2016;16(1). Available from: http://bmcmededuc.biomedcentral. com/articles/10.1186/s12909-016-0704-3

16. Rothmund WL. Oral manifestations of menopause: an interprofessional intervention for dental hygiene and physician assistant students. 2016;

17. Schwarz B. Interprofessional education in the clinical setting: An exploration of the attitudes, knowledge, and skills of physical therapist students and physical therapist clinical instructors; 2017.
18. Scott AD. Simulation-Based Interprofessional Education in a Rural Setting; 2017.

19. Bolesta S, Chmil JV. Interprofessional education among student health professionals using human patient simulation. Am J Pharm Educ. 2014;78(5):94.

20. Kirwin J, Greenwood KC, Rico J, Nalliah R, DiVall M. Interprofessional Curbside Consults to Develop Team Communication and Improve Student Achievement of Learning Outcomes. Am J Pharm Educ. 2017;81(1):15.

21. Sevin AM, Hale KM, Brown NV, McAuley JW. Assessing interprofessional education collaborative competencies in service-learning course. Am J Pharm Educ. 2016;80(2):32.

22. Baker MJ, Durham CF. Interprofessional Education: A Survey of Students' Collaborative Competency Outcomes. J Nurs Educ. 2013 Dec 1;52(12):713-8.

23. Alanazi AA, Nicholson N, Thomas S. The Use of Simulation Training to Improve Knowledge, Skills, and Confidence Among Healthcare Students: A Systematic Review. Internet J Allied Health Sci Pract. 2017;15(3):2.

24. Velentzas J, Broni DG. Communication cycle: Definition, process, models and examples. In: Proceeding of the 5th International Conference on Finance, Accounting and Law (ICFA" 14) [Internet]. 2014:117-31. Available from: http:// www.wseas.us/e-library/conferences/2014/ Istanbul/FINANCE/FINANCE-17.pdf 